\title{
Potential of physiologically based pharmacokinetics to amalgamate kinetic data of trichloroethylene and tetrachloroethylene obtained in rats and man
}

\author{
A KOIZUMI \\ From the Department of Hygiene, Akita University School of Medicine, Akita 010, Japan
}

\begin{abstract}
A physiologically based pharmacokinetic model was used to amalgamate information obtained in rats and man by various routes of exposure to trichloroethylene (TRI) and tetrachloroethylene (TETRA). Since there have been no pharmacokinetic data on drinking water exposure, drinking water exposure to TRI was conducted in rats using ${ }^{14} \mathrm{C}-\mathrm{TRI}$. Several partition coefficients of TRI and TETRA were also determined in the present study. Simulations of the kinetics of TRI and TETRA were made with the unified physiologically based pharmacokinetic model to determine whether reported pharmacokinetic data from different routes of exposure to TRI and TETRA (inhalation, intravenous, drinking water in rats, and inhalation in man) could be simulated. The results indicated that the unified model used in this study successfully simulates the pharmacokinetics of TRI and TETRA irrespective of the routes and exposure intensities. Subsequently, sensitivity analyses were performed. Since both TRI and TETRA require bioactivation to produce their toxicity, the amounts metabolised in the body were used as indicators of toxicity. Vmax (maximum velocity of metabolism in the liver), alveolar ventilation, and the blood/air partition coefficient had a more profound effect than other factors on the amounts of these chemicals metabolised when parameter values were altered. The model was applied to simulate the biologically permissible values of exhaled air concentration and blood concentration of these compounds for monitoring exposure intensities in occupational settings. The simulated maximum permissible values showed good agreement with those obtained by field studies. Finally, the model was applied to the risk assessment of drinking water exposures to TRI and TETRA, assuming that a man weighing $70 \mathrm{~kg}$ drinks 21 of the most contaminated drinking water ever reported in the US; $32 \mathrm{ppb}$ for TRI and $5 \mathrm{ppb}$ for TETRA. The simulated metabolised amounts of TRI and TETRA under steady state condition in man were a fifth of an order of magnitude lower than non-cancer causing metabolised amounts of TRI and TETRA in rats through inhalation.
\end{abstract}

One of the tasks of toxicology is to provide information on the risk to man from exposure to environmental contaminants. Toxicological data are mostly limited to animals except in cases where human data are incidentally collected after accidental exposures. Therefore, in most cases dose response relations established in animals have been used to assess the human risk. The basis of this approach resides in the concept that animals may be sensitive substitutes for the prediction of human toxicity. This assumption is hypothetical yet widely accepted and has been treated as the axiom for rationalising animal experimentation.

Accepted 21 March 1988
In addition to this assumption, there remains another gap between animal experiments and real conditions of human exposure; the exposure routes in man are not necessarily the same as those in the animal experiments. In animal experiments the dose may imply either the amount of chemicals injected or the concentration of chemicals in feed, or the exposure concentration in the inspired air. Thus the constants derived from these results are usually expressed as constants in a route dependent manner such as LC50, LD50, and LT50. From the viewpoint of human risk assessment, however, doses expressed by the route dependent manner have limited applications.

The core assumption of the dose response analysis is 
that there exists a direct correspondence between the dose or inspired air concentration and the "effective concentration $\times$ time" in the body. Therefore, if the internally achieved concentration $x$ time products in the body are estimated from the external doses, a uniform dose response relation may be established in a route independent manner. ${ }^{1}$

The physiologically based pharmacokinetic model (PPM) appears to be a promising tool for obtaining dose response relations on the basis of inner doses, ${ }^{1}$ and thus enables the calculation of the internally achieved concentration $x$ time products in man by scaling up from animals. ${ }^{2}$ By contrast, interspecies extrapolation is impossible by conventional compartment pharmacokinetic modelling because parameters in the compartment model do not have a sound physiological basis. ${ }^{2}$ A drawback of PPM, however, is that it requires more information than compartment models including metabolic constants, tissue/blood partition coefficients, and cardiac output. Vmax (maximum velocity of metabolism) and $\mathrm{km}$ (Michaelis constant) in animals/man and the partition coefficients in human tissues are especially difficult to obtain from reports and even when found, may vary by an order of magnitude. Therefore, unavoidable errors in parameter values may result in cumulative errors which may affect the simulated results. PPM can be described with a set of non-linear differential equations and, theoretically, the sensitivity of the simulated results to changes in the parameters should differ; small changes in some parameters may have profound influences on simulation results whereas changes in other parameters do not. Owing to non-linearity of the equations, the sensitivity is also a function of the dose: some parameters may have a more predominant influence at unsaturated levels, whereas the reverse may be the case for other parameters. Thus a logical question is, to what degree do perturbations of the individual parameters affect the final simulation results at a given dose?

The present study was conducted with the hope of establishing algorithms in applying a physiologically based pharmacokinetic model in animals to human toxicology. Firstly, the applicability of the five tissue compartment model to a pair of prototype chemicals, a highly metabolised compound, and a poorly metabolised compound was examined. Trichloroethyelene (TRI) and tetrachloroethylene (TETRA) were selected as examples of the former and latter compounds, respectively. ${ }^{3}$ In this process the model was applied to exposure monitoring in occupational settings. Secondly, sensitivity analyses by changing parameter values was carried out to find more determinative parameters. Finally, this model was applied to the human risk assessment of TRI and TETRA via drinking water ingestion.

\section{Materials and methods}

DRINKING WATER EXPOSURE

The drinking water exposure experiment was conducted using rats. Radioactive trichloroethylene $\left({ }^{14} \mathrm{C}\right.$ TRI; uniformly labelled) of specific activity $11.3 \mathrm{mCi} /$ mmol was obtained from New England Nuclear. The radiochemical purity after purification was found to be more than $98 \%$. For administration to animals, a solution was prepared by stirring ${ }^{14} \mathrm{C}$-TRI in water for eight hours, giving a final concentration of $5 \mu \mathrm{g} / \mathrm{ml}$, as determined by radioactivity counting. Male OsborneMendel rats (240-260 g) were obtained from CAMM Research Laboratory (Wayne, NJ) and acclimatised to the laboratory for at least seven days before use. Drinking water exposure was carried out essentially as described by Franz and Watanabe. ${ }^{4}$ Four rats were placed in all glass metabolic cages designed to allow separate collection of urine, faeces, expired air, and $\mathrm{CO}_{2}$. Food and a solution of ${ }^{14} \mathrm{C}$-TRI were presented at 12 midnight and at 0800 the next morning and fresh water was substituted for the solution of ${ }^{14} \mathrm{C}$-TRI. The rats were allowed free access to food and water until they were killed 48 hours later ( 56 hours after beginning the exposure). Activated charcoal traps served to absorb ${ }^{14} \mathrm{C}$-TRI and ethanolamine traps collected ${ }^{14} \mathrm{C}$ $\mathrm{CO}_{2}$. The charcoal traps were changed $4,8,10,12,16$, $20,24,32,44$, and 56 hours after starting administration of TRI. $\mathrm{CO}_{2}$ traps were changed $8,12,16,24,32$, and 48 hours after administration. The rats were killed and the carcasses skinned, weighed, and homogenised. Radioactivities of weighted aliquots of the carcase and faecal homogenates were determined with a Harvey biological material oxidiser (Hillsdale, NJ). Radioactivity in the urine samples was determined by direct scintillation counting. In the present experiment the recoveries of the radioactivity were more than $90 \%$.

PHYSIOLOGICALLY BASED PHARMACOKINETIC MODELLING

A physiologically based pharmacokinetic model composed of five tissue groups which was developed by Ramsey and Andersen ${ }^{2}$ was used throughout this study (fig 1). The simultaneous differential equations used to describe the pharmacokinetic behaviour of TRI and TETRA in these models are listed in the appendix. Abbreviations and symbols are given in table 1 .

PHYSIOLOGICAL PARAMETERS

Parameter estimations used have been outlined by Ramsey and Andersen. ${ }^{2}$

Body weight-Mean body weights of animals or human volunteers in the reported experiments were used. 


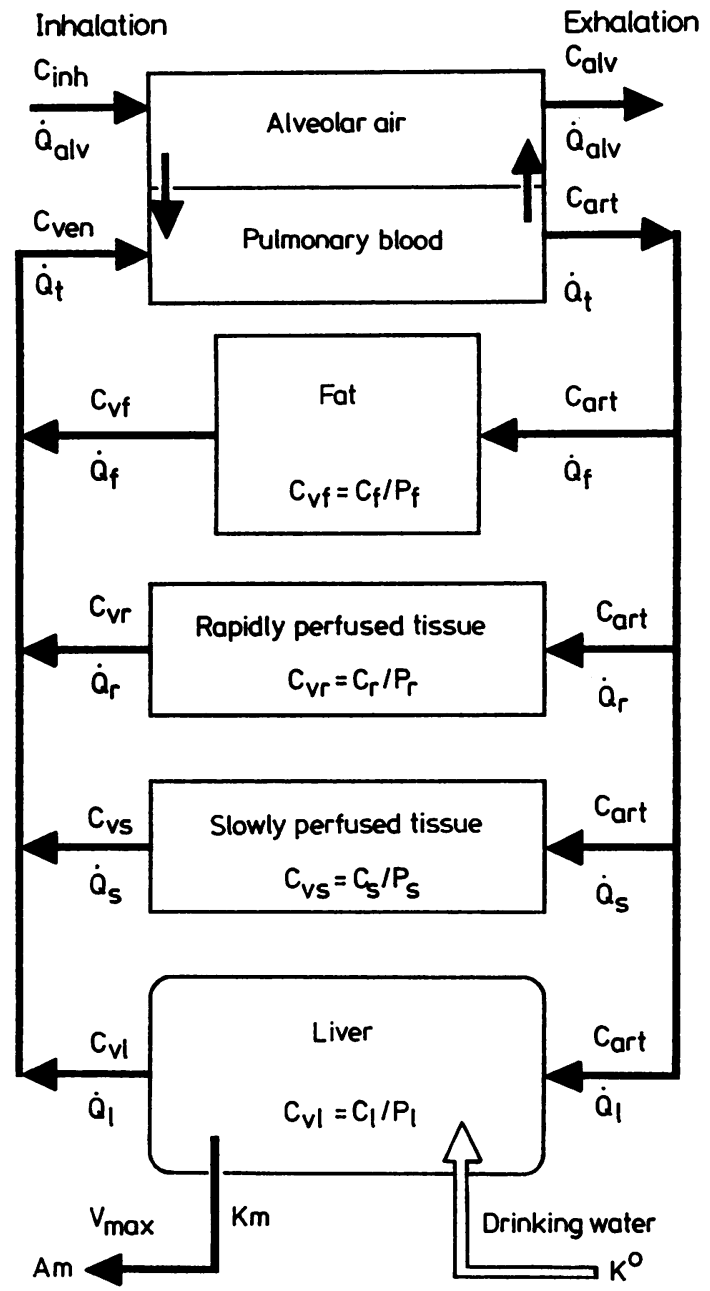

Fig 1 Schematic representation of physiologically based pharmacokinetic model. Symbols: refer to table 1.

Volume of tissue compartments-Volume of individual tissue compartments (in litres) were obtained as the product of the total body weight and relative percentage of each tissue, assuming a unit density $(1 \mathrm{~g} / \mathrm{ml})$ for all tissues. The relative percentages of individual tissue compartments in man were taken from the paper of Davis and Mapleson, ${ }^{5}$ as shown in table 2. Relative percentages of the tissue compartments in rats were taken from the paper of Ramsey and Andersen, ${ }^{2}$ as summarised in table 2.

Cardiac output and alveolar ventilation-Cardiac output and alveolar ventilation in man were both taken from the paper of Davis and Mapleson. ${ }^{5}$ The authors' values, however, were used when alveolar ventilations were measured by them. Cardiac output
Table 1 Abbreviations and symbols used in a physiologically based pharmacokinetic model

\begin{tabular}{|c|c|c|}
\hline $\begin{array}{l}\text { Abbreviation } \\
\text { or symbol }\end{array}$ & Description & Unit \\
\hline $\begin{array}{l}\text { BW } \\
Q_{\text {alv }} \\
C_{\text {inh }} \\
C_{\text {alv }} \\
C_{\text {exh }} \\
N^{\prime} \\
Q_{t} \\
C_{\text {ant }} \\
C_{\text {ven }} \\
\text { Vmax } \\
\text { Km } \\
\text { Am } \\
\text { Amst }\end{array}$ & $\begin{array}{l}\text { Body weight } \\
\text { Alveolar ventilation } \\
\text { Concentration in inhaled air } \\
\text { Concentration in alveolar air } \\
\text { Concentration in exhaled air } \\
\text { Blood/air partition coefficient } \\
\text { Cardiac output } \\
\text { Concentration in arterial blood } \\
\text { Concentration in venous blood } \\
\text { Maximum enzymatic reaction rate } \\
\text { Michaelis constant } \\
\text { Amount metabolised } \\
\text { Amount metabolised under steady } \\
\text { state }\end{array}$ & $\begin{array}{l}\mathrm{Kg} \\
\mathrm{l} / \mathrm{h} \\
\mathrm{mg} / 1 \\
\mathrm{mg} / 1 \\
\mathrm{mg} / 1 \\
\mathrm{mg} / 1 \\
\mathrm{l} / \mathrm{h} \\
\mathrm{mg} / 1 \\
\mathrm{mg} / 1 \\
\mathrm{mg} / 1 \\
\mathrm{mg} / 1 \\
\mathrm{mg} / 24 \mathrm{~h} \\
\mathrm{mg} / 24 \mathrm{~h}\end{array}$ \\
\hline $\begin{array}{l}\text { Subscription } \\
\\
\text { Qi } \\
\mathrm{Vi} \\
\mathrm{Ci} \\
\mathrm{Cvi} \\
\mathrm{Pi}\end{array}$ & $\begin{array}{l}\text { tissue groups or compartments: } \\
\text { l Liver } \\
\text { f Fat tissue } \\
\text { r Rapidly perfused tissue } \\
\text { s Slowly perfused tissue } \\
\text { Blood flow rate to tissue group } \\
\text { Volume of tissue group } \\
\text { Concentration in tissue group } \\
\text { Concentration in venous blood } \\
\text { Tissue/blood partition coefficient }\end{array}$ & $\begin{array}{l}\mathrm{l} / \mathrm{h} \\
\mathrm{l} \\
\mathrm{mg} / \mathrm{l} \\
\mathrm{mg} / \mathrm{l} \\
-\end{array}$ \\
\hline
\end{tabular}

and alveolar ventilation for different weights were scaled to the 0.7 power of body weight, as outlined by Ramsey and Andersen. ${ }^{2}$

Flow to the tissue groups-Flow to the individual tissue groups was obtained from the product of the relative percentage of flow to each tissue and appropriate cardiac output. It was assumed that the same percentage of cardiac output would perfuse the tissue groups in rat and man and the percentages were taken from the paper of Davis and Mapleson.

\section{PARTITION COEFFICIENTS}

Tissue/air partition coefficients were determined for human blood and rat blood, liver, fat, and muscle using the vial equilibrium technique of Sato and Nakajima. ${ }^{6}$ On the sampling date, blood and tissues were collected from three male rats. Blood and tissues were then pooled. Liver and muscle were homogenised with isotonic saline solution $(25 \% \mathrm{w} / \mathrm{w})$. When liver or muscle/air partition coefficient was calculated, the dilution of the homogenates with saline was compensated by a method described by Sato and Nakajima. ${ }^{6}$ Fat tissues were pulverised at the temperature of liquid nitrogen and then pooled. Human blood samples were collected from three male volunteers on the day of the determination and measured individually. Tissue or blood air partition coefficients were determined by a gas chromatographic method, using a Perkin-Elmermodel F-45 head space analyser equipped with a flame ionisation detector and a Hewlett Packard model 3388 A integrator. Tissue/blood partition coefficients for 
Table 2 Parameters in the physiologically based pharmacokinetic model for TRI and TETRA

\begin{tabular}{|c|c|c|}
\hline Tissue volume (l) & Rat & Man \\
\hline $\begin{array}{l}\text { Liver } \\
\text { Rapidly perfused tissue } \\
\text { Slowly perfused tissue } \\
\text { Fat tissue } \\
\text { Flow (1/h) } \\
\text { Alveolar ventilation } \\
\text { Cardiac output } \\
\text { Liver } \\
\text { Rapidly perfused tissue } \\
\text { Slowly perfused tissue } \\
\text { Fat tissue }\end{array}$ & $\begin{array}{r}(B W) \times 0.041 \\
(B W) \times 0.062 \\
(B W) \times 0.635 \\
(B W) \times 0.071 \\
(B\end{array}$ & $\begin{array}{l}(B W) \times 0.026 \\
(B W) \times 0.031 \\
(B W) \times 0.524 \\
(B W) \times 0.195 \\
607 \\
636\end{array}$ \\
\hline
\end{tabular}

Partition coefficient:

\begin{tabular}{|c|c|c|c|c|}
\hline \multicolumn{3}{|c|}{ Trichloroethylene } & \multicolumn{2}{|c|}{ Tetrachloroethylene } \\
\hline & Rat & Man & Rat & Man \\
\hline \multirow{4}{*}{$\begin{array}{l}\text { Blood/air } \\
\text { Liver/air } \\
\text { Rapidly perfused } \\
\text { tissue/air } \\
\text { Slowly perfused } \\
\text { tissue/air } \\
\text { Fat/air }\end{array}$} & $\begin{array}{l}25 \cdot 8 \\
62.7\end{array}$ & $\begin{array}{c}9.77 \\
62.7\end{array}$ & $\begin{array}{l}12.9 \\
45.7\end{array}$ & $\begin{array}{l}11.0 \\
45.7\end{array}$ \\
\hline & $62 \cdot 7$ & $62 \cdot 7$ & $45 \cdot 7$ & $45 \cdot 7$ \\
\hline & & & & \\
\hline & $\begin{array}{l}21 \cdot 6 \\
614\end{array}$ & $\begin{array}{l}21 \cdot 6 \\
614\end{array}$ & $\begin{array}{l}19 \cdot 7 \\
1301\end{array}$ & $\begin{array}{l}19 \cdot 7 \\
1301\end{array}$ \\
\hline \multicolumn{5}{|c|}{ Metabolic constant: } \\
\hline $\begin{array}{l}\mathrm{Vm} \\
\mathrm{Km}\end{array}$ & \multicolumn{2}{|c|}{$\begin{array}{l}10 \times(\mathrm{BW})^{0.7} \\
2.5\end{array}$} & \multicolumn{2}{|c|}{$\begin{array}{l}0.528 \times(\mathrm{BW})^{0.7} \\
1.0\end{array}$} \\
\hline
\end{tabular}

rat fat, muscle, and liver were calculated by the ratio of the measured tissue/air partition coefficient by the blood/air coefficient for rat blood. Tissue/blood coefficients for man were estimated by dividing the measured tissue/air coefficient for corresponding rat tissue by the blood/air coefficient for man.

\section{MAXIMUM METABOLIC VELOCITY (VMAX) AND MICHAELIS CONSTANT (KM)}

The Vmax and $\mathrm{km}$ in the model were estimated in the stepwise manner. When the exposure intensity is substantially less than metabolic saturation, the nonlinear term in the Michaelis-Menten equations may be approximated as:

$$
\frac{V \max \times\left(\mathbf{C}_{1} / \mathbf{P}_{1}\right)}{\mathrm{Km}+\left(\mathbf{C}_{1} / \mathbf{P}_{1}\right)} \cong\left(\frac{V \max }{\mathrm{Km}}\right)\left(\frac{\mathrm{C}_{1}}{\mathbf{P}_{1}}\right)
$$

where $V \max , \mathrm{km}, \mathrm{C}_{1}$, and $P_{1}$ are constants used in the model (table 1) and $K$ is equal to $V \max / \mathrm{km}$. Thus the equation may be treated as a first order kinetic. The value $K$ was obtained by optimisation and once obtained, the equation may be written using Vmax and $\mathbf{k}$ :

$$
\frac{\operatorname{Vmax} \times\left(\mathbf{C}_{1} / \mathbf{P}_{1}\right)}{\mathrm{Km}+\left(\mathbf{C}_{1} / \mathbf{P}_{1}\right)}=\frac{V \max \times\left(\mathbf{C}_{1} / \mathbf{P}_{1}\right)}{\operatorname{Vmax} / \mathbf{K}+\left(\mathbf{C}_{1} / \mathbf{P}_{1}\right)}
$$

Hence Vmax will be optimised using the known $\mathrm{K}$, based on data after the exposure to doses that saturate the metabolism.
In the present study the approximate values of $K$ for TRI and TETRA were estimated from the data on amounts metabolised after inhalation exposure at $10 \mathrm{ppm}$ for six hours generated by Stott et $\mathrm{al}^{7}$ and Pegg et al, ${ }^{8}$ respectively. Subsequently, Vmaxs for TRI and TETRA were estimated from corresponding data on the extents of metabolism after inhalation exposures at $600 \mathrm{ppm}$ for six hours reported. ${ }^{78}$ At these intensities of exposures, metabolism for these compounds were saturated. ${ }^{378}$

\section{COMPUTER SIMULATION}

Simulation of differential equations (appendix) describing the kinetics of TRI and TETRA were formulated as a computer program as outlined by Ramsey and Andersen. ${ }^{2}$ Simulations were conducted with a software package developed by Agin and Blau and were run on an IBM computer.

\section{Results}

\section{PARAMETERS}

Algorithms for estimating physiological parameters from body weights are listed in table 2 , and are similar to those applied by Ramsey and Andersen. ${ }^{2}$ Partition coefficients determined in this study and subsequently used in the model are listed in table 3. Estimation of metabolic constants is discussed in the next section.

\section{SIMULATION OF PHARMACOKINETICS OF TRI}

\section{AFTER VARIOUS ROUTES OF EXPOSURE IN RATS}

AND MAN

The physiological model, which uses the parameters in tables 2 and 3, was applied to the fates of TRI after several routes of exposure in rats and man. The various sources of data used are cited in table 4.

Estimation of Vmax and $\mathrm{Km}-\mathrm{Vmax}$ and $\mathrm{Km}$ for TRI were estimated from metabolised amounts reported by Stott $e t$ al $^{7}$ after exposure to $10 \mathrm{ppm}$ and 600 $\mathrm{ppm}$ for six hours. At the latter exposure intensity, the metabolism of TRI was saturated. The obtained Vmax and $\mathrm{Km}$ (standardised to $1 \mathrm{~kg}$ body weight) was 10 $\mathrm{mg} / \mathrm{h}$ and $2.5 \mathrm{mg} / \mathrm{l}$, respectively. The body burdens (mg eq of TRI $/ \mathrm{kg}$ ) for these exposures simulated using the Vmax and $\mathrm{Km}$ are 5.56 at $10 \mathrm{ppm}$ and 240 at 600 ppm whereas the observed body burdens corresponding to these exposure intensities were 4.7 and 141 , respectively (table 5 ). Finally, the simulated proportions of the total body burden uptake of TRI exhaled showed a good agreement with those observed (simulated \%/observed \%) $31 \cdot 8 \% / 21 \cdot 1 \%$ at $600 \mathrm{ppm}$ and $2 \cdot 6 \% / 2 \cdot 1 \%$ at $10 \mathrm{ppm}$.

Drinking water exposure in rats-In the simulations it was assumed that TRI ingested with water directly enters the liver as expressed in zero order kinetics (fig 1; $\mathrm{K}^{0}$ ). It was also assumed that rats drank water 
Table 3 Partition coefficients of TRI and TETRA at $37^{\circ} \mathrm{C}$

\begin{tabular}{|c|c|c|c|c|c|c|}
\hline \multirow{2}{*}{$\begin{array}{l}\text { Tissue } \\
\text { or reference } \\
\text { substance }\end{array}$} & \multicolumn{3}{|c|}{ Trichloroethylene } & \multicolumn{3}{|c|}{ Tetrachloroethylene } \\
\hline & $-/ A i r^{*}$ & $\begin{array}{l}\text { Rat } \dagger \\
-/ \text { blood }\end{array}$ & $\begin{array}{c}\text { Humant } \\
-/ \text { blood }\end{array}$ & $-/ A i r^{*}$ & $\begin{array}{l}\text { Rat } † \\
- \text { lblood }\end{array}$ & $\begin{array}{c}\text { Humant } \\
- \text {-lblood }\end{array}$ \\
\hline $\begin{array}{l}\text { Water } \\
\text { Saline } \\
\text { Rat blood } \\
\text { Human blood } \\
\text { Liver } \\
\text { Muscle } \\
\text { Fat }\end{array}$ & $\begin{array}{l}2.62 \pm 0.30 \\
3.18 \pm 0.85 \\
25.8 \pm 2.78 \\
9.77 \pm 0.23 \\
62.7 \pm 6.83 \\
21.6 \pm 4.00 \\
615 \pm 25.5\end{array}$ & $\begin{array}{l}- \\
- \\
\overline{2.43 \dagger} \\
0 \cdot 84 \dagger \\
23 \cdot 8 \dagger\end{array}$ & $\begin{array}{l}- \\
- \\
\overline{6.41 \ddagger} \\
2.21 \ddagger \\
68.9 \ddagger\end{array}$ & $\begin{array}{l}0.85 \pm 0.13 \\
0.73 \pm 0.18 \\
12.9 \pm 1.61 \\
11.0 \pm 0.76 \\
45.7 \pm 7.40 \\
19.7 \pm 10.2 \\
1301 \pm 87\end{array}$ & $\begin{array}{l}- \\
- \\
- \\
3 \cdot 54 \dagger \\
1.52 \dagger \\
100 \cdot 7 \dagger\end{array}$ & $\begin{array}{l}- \\
- \\
- \\
4 \cdot 17 \ddagger \\
1.79 \ddagger \\
118.6 \ddagger\end{array}$ \\
\hline
\end{tabular}

*Values are mean \pm SD of triplicate determinations.

†Partition coefficients were calculated as the ratio between tissue/air and blood/air values.

$\ddagger$ Rat liver/air, muscle/air, and fat/air divided by human blood/air values.

Table 4 Summary of routes, species, and data sources

\begin{tabular}{|c|c|c|c|c|}
\hline Chemical & Route & Dose & Species & Reference \\
\hline \multirow[t]{2}{*}{ TRI } & $\begin{array}{l}\text { Inhalation } \\
\text { Drinking } \\
\text { water }\end{array}$ & $\begin{array}{c}600 \mathrm{ppm} \times 6 \mathrm{~h} \\
10 \mathrm{ppm} \times 6 \mathrm{~h} \\
5 \mu \mathrm{g} / \mathrm{ml} \\
\times 8 \mathrm{~h}\end{array}$ & $\begin{array}{l}\text { Rat } \\
\text { Rat } \\
\text { Rat }\end{array}$ & $\begin{array}{l}7 \\
7 \\
\text { In the } \\
\text { present } \\
\text { study }\end{array}$ \\
\hline & $\begin{array}{l}\text { Intravenous } \\
\text { Inhalation } \\
\text { Inhalation } \\
\text { Drinking }\end{array}$ & $\begin{array}{l}3-15 \mathrm{mg} / \mathrm{kg} \\
100 \mathrm{ppm} \times 4 \mathrm{~h} \\
600 \mathrm{ppm} \times 6 \mathrm{~h}\end{array}$ & $\begin{array}{l}\text { Rat } \\
\text { Man } \\
\text { Rat }\end{array}$ & $\begin{array}{r}10 \\
11 \\
8\end{array}$ \\
\hline \multirow{2}{*}{ TETRA } & $\begin{array}{l}\text { water } \\
\text { Inhalation }\end{array}$ & $\begin{array}{l}8.1 \mathrm{mg} / \mathrm{kg} \\
144 \mathrm{ppm} \times 4 \mathrm{~h}\end{array}$ & Rat & 4 \\
\hline & & $72 \mathrm{ppm} \times 4 \mathrm{~h}$ & Man & 12 \\
\hline
\end{tabular}

continuously during the exposure. As shown in table 5 , the simulated value of exhaled TRI is $10.8 \%$ of the dose whereas the corresponding observed value was $14.5 \%$.

Intravenous administration in rats-The model was applied to the pharmacokinetics of TRI given intravenously. ${ }^{10}$ The doses ranged from 3 to $15 \mathrm{mg} / \mathrm{kg}$. The administered TRI was considered to have been mixed instantaneously. The simulated and reported data are depicted in fig 2.

Human inhalation-Sato and Nakajima have reported the pharmacokinetics of TRI in human volunteers. " They reported time course profiles of concentrations in blood and exhaled air from the end of the four hours exposure up to 14 hours later. Metabolic constants and physiological parameters are scaled up in the model. The simulated and reported values were illustrated in fig 3. As shown in table 6, biomonitoring values in blood and expired air after exposures to 50 ppm of TRI determined by historical experience in occupational settings are also predicted by simulation.

SIMULATION OF PHARMACOKINETICS OF TETRA AFTER VARIOUS ROUTES OF EXPOSURE IN RATS AND MAN

The physiological model was applied to the fates of TETRA after several routes of exposure in rats and man. The various sources of data used are cited in table 4.

Estimation of Vmax and $\mathrm{Km}$-Values of Vmax and $\mathrm{Km}$ for TETRA were estimated from data on the amounts metabolised, as generated by Pegg et al. ${ }^{8}$ The authors clearly show that the metabolism of TETRA was heavily saturated at $600 \mathrm{ppm}$ exposure with $68 \%$ being exhaled as a parent compound at $10 \mathrm{ppm}$, and $88 \%$ at $600 \mathrm{ppm}$. The obtained Vmax and $\mathrm{Km}$ (standardised to $1 \mathrm{~kg}$ body weight) were $0.5278 \mathrm{mg} / \mathrm{h}$ and $1.0 \mathrm{mg} / \mathrm{l}$ respectively). Table 7 shows the reported and simulated body burdens. The rates of exhalation of TETRA after inhalations at $600 \mathrm{ppm}$ and $10 \mathrm{ppm}$ were simulated from the end of the exposure up to $60 \mathrm{~h}$ (fig 4). Blood concentrations were also simulated (fig 4).

Drinking water exposure in rats-Frantz and Watanabe have generated pharmacokinetic data on TETRA via drinking water ingestion. ${ }^{4}$ They reported that the percentage exhaled as a parent compound was $87.9 \%$ whereas simulation gives $70 \cdot 6 \%$.

Human inhalation-Monster et al investigated the pharmacokinetics of TETRA in human volunteers who were exposed for four hours to 72 or $144 \mathrm{ppm} .{ }^{12}$ In that study body burdens were estimated in the same way as in the present study-the product of the difference between exhaled and inhaled concentrations of TETRA and minute volumes. As alveolar ventilation $(6 \mathrm{l} / \mathrm{h})$ was calculated by Monster et $\mathrm{l}^{12}$ this number was used instead of the scaled up value $(4 \cdot 7$ $1 / h)$. The body burdens estimated by them after the exposure to $72 \mathrm{ppm}$ or $144 \mathrm{ppm}$ was 455 and $945 \mathrm{mg} \mathrm{eq}$ of TETRA, whereas the corresponding estimated values are $432 \mathrm{mg}$ eq of TETRA at $72 \mathrm{ppm}$ and $863 \mathrm{mg}$ eq of TETRA at $144 \mathrm{ppm}$ (table 7). The observed and simulated time profiles of TETRA concentrations in the blood and in exhaled air at 72 and $144 \mathrm{ppm}$ are shown in fig 5 . As shown in table 6 biomonitoring values in blood and expired air after exposures to 50 ppm of TETRA determined by historical experience in occupational settings are predicted by simulation. ${ }^{13}$ 
Table 5 Observed and simulated per cent exhalation of TRI and body burden in rats

\begin{tabular}{|c|c|c|c|c|c|}
\hline \multirow[b]{2}{*}{ Route } & \multirow[b]{2}{*}{ Exposure intensity } & \multicolumn{2}{|c|}{$\%$ Exhaled* } & \multicolumn{2}{|c|}{ Total body burden ( $\mathrm{mg} E q / \mathrm{kg}$ ) } \\
\hline & & Observedt & Simulation & Observedt & Simulation \\
\hline $\begin{array}{l}\text { Inhalation } \\
\text { Drinking water }\end{array}$ & $\begin{array}{r}10 \mathrm{ppm} \times 6 \mathrm{~h} \\
600 \mathrm{ppm} \times 6 \mathrm{~h} \\
5 \mu \mathrm{g} / \mathrm{ml} \times 8 \mathrm{~h}\end{array}$ & $\begin{array}{r}2 \cdot 1 \\
21 \cdot 1 \\
14 \cdot 5\end{array}$ & $\begin{array}{r}2.6 \\
31.8 \\
10.8\end{array}$ & $\begin{array}{c}141^{4 \cdot 70} \\
0.442\end{array}$ & $\begin{array}{c}5 \cdot 56 \\
240 \\
0.442\end{array}$ \\
\hline
\end{tabular}

*\% Exhaled in inhalation study was defined as;

$\%$ Exhaled $=\frac{\text { Exhaled }{ }^{14} \mathrm{C}-\mathrm{TRI}}{\text { Total recovered radioactivity }} \times 100$

‡Stott et al.' (body burden)

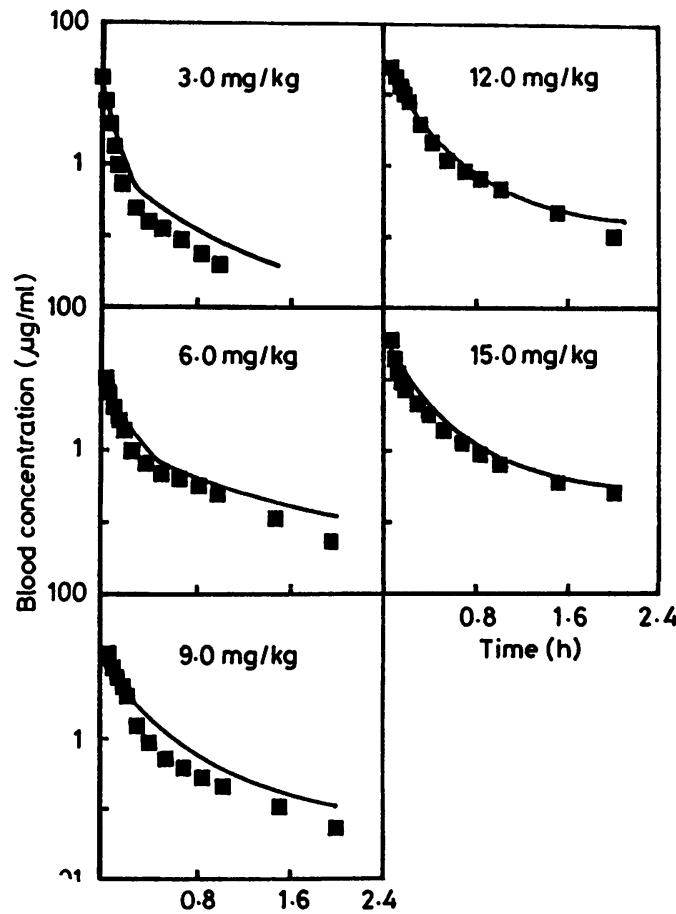

Fig 2 Simulated and observed time course of TRI in blood after intravenous administration (3-15 $\mathrm{mg} / \mathrm{kg}$ ). Withey and Collins applied two or three compartments model to describe time course of blood concentration of TRI after intravenous administration. ${ }^{10}$ Each time point value (solid square) was calculated using reported equations. Mean animal weight reported was $400 \mathrm{~g}$. Continuous lines are drawn by simulation.

\section{SENSITIVITY ANALYSIS}

The risk posed by exposure to those chemicals that require bioactivation to produce toxicity may be evaluated by the rate of amount metabolised as discussed below. Accordingly, sensitivity analyses were performed to investigate the influence of perturbations in the parameters on the rate of amount metabolised during 24 hours. In the simulation the

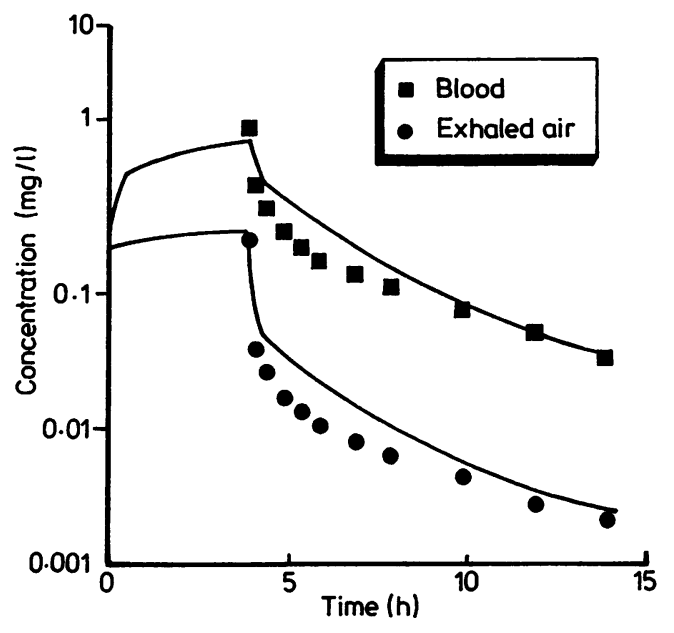

Fig 3 Simulated and observed time course of TRI in blood and expired air in man after four hours exposure to $100 \mathrm{ppm}$. Sato and Nakajima reported blood concentrations and expired air concentrations of TRI in human volunteers (mean body weight $62 \mathrm{~kg}$ ) after end of a four hour exposure to TRI at 100 ppm." Blood samples were collected at 0, 0.17, 0.5, and one hour intervals thereafter up to 10 hours after the exposure. The expired air concentrations were collected at 0 , $0 \cdot 17,0 \cdot 5,1 \cdot 0,1 \cdot 5,2 \cdot 0,3 \cdot 0,4 \cdot 0$, and two hour intervals up to 10 hours after end of exposure. In figure, solid circles of blood $\dot{\varnothing}$ and exhaled air concentrations represent observed values whereas continuous lines represent simulation results.

amount metabolised (Am) was defined as:

$$
A m=\int_{0}^{24} \frac{V \max \times\left(C_{1} / P_{1}\right)}{K m+\left(C_{1} / P_{1}\right)} d t
$$

Each parameter was sequentially increased by $200 \%$ 웅 As shown in table 8, sensitivity to the parameters is a function of exposure intensity. At low exposures (10 $\mathrm{ppm}), \mathrm{Vmax}$ is a less determinative parameter for $\mathrm{Am}_{\square}$ than alveolar ventilation rate $(64 \%)$ for TRI or has about the same influence as blood/air partition $\stackrel{\mathbb{\triangle}^{\circ}}{ }$

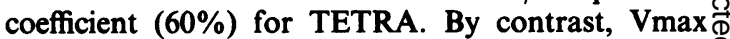
becomes the principal parameter $\left(49 \%\right.$ for TRI and $\frac{\varrho}{\sigma}$ 
Table 6 Biological permissible values for TRI and TETRA determined by simulation versus historical experience

\begin{tabular}{llll}
\hline & & $\begin{array}{l}\text { Tentative permissible value* } \\
\text { (Simulated value) } \dagger\end{array}$ \\
\cline { 3 - 4 } Solvent & Threshold limit value & $\begin{array}{l}\text { Solvent in } \\
\text { blood }\end{array}$ & $\begin{array}{l}\text { Solvent in } \\
\text { expired air }\end{array}$ \\
\hline TRI & $50 \mathrm{ppm}, 8 \mathrm{~h}$ & $\begin{array}{l}0.9 \mathrm{mg} / \mathrm{l} \ddagger \\
(0.8)\end{array}$ & $\begin{array}{l}50-80 \mathrm{mg} / \mathrm{m}^{3} \ddagger \\
(50)\end{array}$ \\
TETRA & $50 \mathrm{ppm}, 8 \mathrm{~h}$ & $2.3 \mathrm{mg} / 1 \S$ & $160 \mathrm{mg} / \mathrm{m}^{3} \S$ \\
& & $(1.8) \|$ & $(120) \|$ \\
\hline
\end{tabular}

*Cited from ref 13.

†Assuming that a $70 \mathrm{~kg}$ body weight man works eight hours with a one hour noon rest.

\pm Values immediately after eight hours work.

$\S$ Values 5 to 15 minutes after eight hours work.

||Simulated values 10 minutes after eight hours work.

$95 \%$ for TETRA) in the Am at $600 \mathrm{ppm}$. In exposure through drinking water, Vmax and $\mathrm{Km}$ of TETRA have a relatively large impact on Am (ca $\pm 50 \%$ ) whereas they have little effect on Am of TRI. By contrast, the tissue/blood partition coefficients consistently have negligible effects of both TRI and TETRA.

\section{RISK ASSESSMENT}

For risk assessment, the total amounts being metabolised under repeated exposure - that is, in a quasi steady state- was chosen as a measure of risk. In the simulation the following parameter was calculated:

Amount metabolised under steady state during $24 \mathrm{~h}$ (Amst)

$$
=\int_{T}^{T+24} \frac{V \max \left(C_{1} / P_{1}\right)}{K m+\left(C_{1} / P_{1}\right)} d t
$$

where $T$ is the time which produces a steady state of the metabolised amount. It is reported that exposure of rats to TRI at $500 \mathrm{ppm}$ for six hours a day, five days a week during the greater part of their life span ${ }^{14}$ and to
TETRA at $600 \mathrm{ppm}$ for six hours a day, five days a week for one year ${ }^{15}$ did not increase the incidence of cancer. Thus the Amst corresponding to these exposure intensities may be assumed to be non-cancer causing internal dose levels for TRI and TETRA in rats, respectively. The highest concentrations so far recorded in drinking water in the United States have been $32 \mathrm{ppb}$ for TRI $^{16}$ and 5 ppb for TETRA. ${ }^{17}$ Assuming that a standard man of $70 \mathrm{~kg}$ body weight drinks 21 of most heavily contaminated drinking water with TRI and TETRA in the United States, the Amst for man was calculated (table 9). The human Amst were approximately a fifth of an order of magnitude lower than those of the corresponding noncancer causing Amst in rats (table 9).

\section{Discussion}

The success of physiologically based pharmacokinetic modelling is totally dependent on the selection of a model and the accuracy of its parameters. As the model becomes more complex, the number of parameters increases and consequently results in increased errors and ambiguity of the parameters. Thus a model should be chosen such that the parameters may be obtained with minimum ambiguity. In the present study a model composed of five tissue compartments was selected and the parameter set necessary for a physiological model obtained in a uniform manner so as to decrease the ambiguity of selecting the parameters. The algorithm used in this study consists of four procedures:

(1) Determination of blood/air partition coefficients for rats and man, and tissues/air partition coefficients for rats using head space analyses.

(2) Calculation of flows and Vmax was based on the 0.7 power of weight.

(3) Optimisation of Vmax and $\mathrm{Km}$ using animal data on the amounts metabolised after non-saturable

Table 7 Observed and simulated per cent exhaled of TETRA and body burden

\begin{tabular}{|c|c|c|c|c|c|}
\hline \multirow[b]{2}{*}{ Species } & \multirow[b]{2}{*}{ Exposure } & \multicolumn{2}{|c|}{$\%$ Exhaled* } & \multicolumn{2}{|c|}{ Total body burden } \\
\hline & & Observed & Simulation $\dagger$ & Observed & Simulation $\dagger$ \\
\hline $\operatorname{Rat}^{8}$ & \multirow{3}{*}{$\begin{array}{l}\text { Inhalation } \\
10 \mathrm{ppm} \times 6 \mathrm{~h} \\
600 \mathrm{ppm} \times 6 \mathrm{~h} \\
\text { Drinking water } \\
150 \mu \mathrm{g} / \mathrm{ml} \\
\text { Inhalation } \\
72 \mathrm{ppm} \times 4 \mathrm{~h} \\
144 \mathrm{ppm} \times 4 \mathrm{~h}\end{array}$} & $\begin{array}{l}68 \cdot 1 \\
88 \cdot 0\end{array}$ & $\begin{array}{l}53.4 \\
89.3\end{array}$ & $510^{5.92^{(\mathrm{mg}}}$ & $\begin{array}{l}\text { 3) } \\
207\end{array}$ \\
\hline & & 87.9 & $70 \cdot 6$ & 8.36 & $8 \cdot 36$ \\
\hline $\operatorname{Man}^{12}$ & & $\begin{array}{l}95 \\
92\end{array}$ & $\begin{array}{l}95 \\
96\end{array}$ & $\begin{array}{l}455 \\
945\end{array}$ & $\begin{array}{c}\text { erson) } \\
432 \\
863\end{array}$ \\
\hline
\end{tabular}

Exhaled in inhalation studies were defined as;

$\%$ Exhaled $=\frac{\text { exhaled TETRA }}{\text { total body burden }} \times 100$

†Simulations were conducted using the model. 

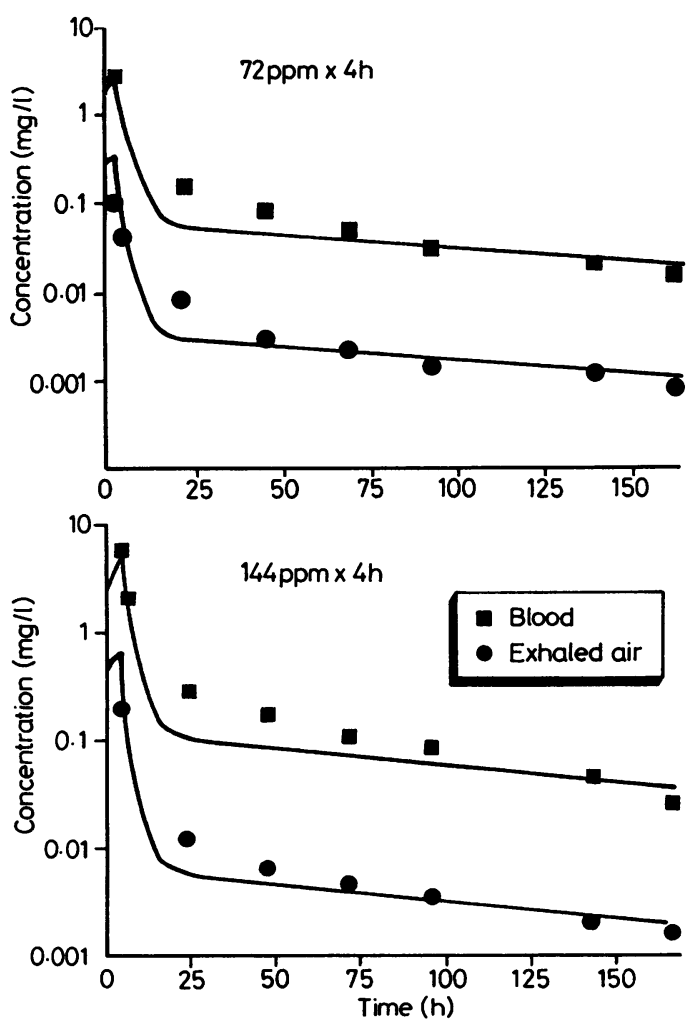

Fig 5 Simulated and observed time course of exhaled air concentrations and blood concentrations of TETRA after four hours exposure to 72 and 144 ppm in man. Monster et al reported time course of expired air concentrations (dots) and blood concentrations (squares) after exposure to $72 \mathrm{ppm}$ and 144 ppm for four hours. ${ }^{12}$ Mean body weight of volunteers was $77 \mathrm{~kg}$. Continuous lines indicate simulation results. and saturable exposures.

(4) The incorporation of the route of exposure in the model with respect to the physiological meaning.

This algorithm was uniformly applied to the fates of TRI and TETRA in rats and man given various $\overrightarrow{0}$ routes. As shown above, the approach simulated the $\&$ kinetics of these compounds fairly well, irrespective of the routes of administration or species except in the case where the simulated body burden $(240 \mathrm{mg}$ $\mathrm{Eq} / \mathrm{kg}$ ) in rats after exposure at $600 \mathrm{ppm}$ of TRI was 1.7 times larger than the observed body burden $(141 \mathrm{mg} \mathrm{Eq} / \mathrm{kg})$. These data showed, therefore, the applicability of the proposed algorithm together with the correctly used five tissue compartment model in most cases.

The sensitivity analyses gave us an insight into the extent that individual parameters may be determinative of simulation results. As shown by the sensitivity analyses for Am of TRI, Vmax had a larger impact on Am than other parameters when exposure intensities were high $(600 \mathrm{ppm})$ but at low exposures $(10 \mathrm{ppm})$ alveolar ventilation had a great impact on Am. By contrast, it is of interest that the partition coefficient 을 has far less predominant effect on Am than the aforementioned parameters. The sensitivity analyses for Am of TETRA showed that at the low exposure dose $(10 \mathrm{ppm})$, blood/air partition coefficient had a $\Omega$ large impact on Am. By contrast, Vmax had a large $N$ effect on Am, irrespective of exposure intensity. Thus the change in Vmax has a greater impact on Am than 0 any other parameter when the amount metabolised is relatively smaller than that exhaled as the parent compound (TETRA) from the lung. This occurs even os after exposures to TRI at high dose levels where 0 metabolic saturation is achieved. By contrast, the $\bar{O}$ effects of changes in blood/air partition coefficient or alveolar ventilation on Am becomes predominant only at low concentrations. Taking these findings 
Table 8 Effects of a $200 \%$ increase in each parameter value on the amounts metabolised

\begin{tabular}{|c|c|c|c|c|c|c|}
\hline & \multicolumn{6}{|c|}{ Amount metabolised (Am:mg/24h)* } \\
\hline & \multicolumn{3}{|c|}{ Trichloroethylene } & \multicolumn{3}{|c|}{ Tetrachloroethylene } \\
\hline & \multicolumn{2}{|l|}{ Rat $(250 \mathrm{~g})$} & $\operatorname{Man}(70 \mathrm{~kg})$ & \multicolumn{2}{|l|}{ Rat $(250 \mathrm{~g})$} & $\operatorname{Man}(70 \mathrm{~kg})$ \\
\hline & $10 \mathrm{ppm} \times 6 \mathrm{~h}$ & $600 \mathrm{ppm} \times 6 \mathrm{~h}$ & $32 p p b \times 2 l$ & $10 \mathrm{ppm} \times 6 \mathrm{~h}$ & $600 \mathrm{ppm} \times 6 \mathrm{~h}$ & $5 p p b \times 2 l$ \\
\hline Control & & & & & & \\
\hline$\%$ & $100^{5.09}$ & $\begin{array}{l}135 \cdot 6 \\
100\end{array}$ & $\begin{array}{l}6.34 \times 10^{-4} \\
100\end{array}$ & $100^{1 \cdot 70}$ & $\begin{array}{l}14 \cdot 7 \\
100\end{array}$ & $100^{3.63 \times 10^{-5}}$ \\
\hline $\begin{array}{l}\text { \% Change of amount metabolised } \\
\text { Vmax } \\
\text { Km } \\
\text { Blood/air } \\
\text { Liver/blood } \\
\text { Fat/blood } \\
\text { Rapidly perfused tissue/blood } \\
\text { Slowly perfused tissue/blood } \\
\text { Alveolar ventilation } \\
\text { Cardiac output }\end{array}$ & $\begin{array}{c}5.6 \\
-9.3 \\
11.8 \\
\text { ng } \\
\text { ng } \\
\text { ng } \\
\text { ng } \\
64 \\
6.1\end{array}$ & $\begin{array}{c}49.4 \\
-7.1 \\
6.0 \\
\text { ng } \\
\text { ng } \\
1.2 \\
4.7 \\
-2.3 \\
1.9\end{array}$ & 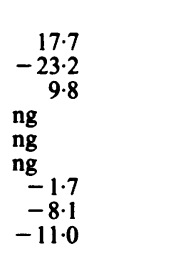 & \begin{tabular}{r}
$59 \cdot 1$ \\
-37.6 \\
60.1 \\
ng \\
\multicolumn{2}{c}{-8.2} \\
ng \\
ng \\
\multicolumn{2}{c}{$7 \cdot 5$} \\
\\
$\quad 9.6$
\end{tabular} & $\begin{array}{r}95 \cdot 2 \\
-13 \cdot 7 \\
12 \cdot 1 \\
\text { ng } \\
-2 \cdot 6 \\
\text { ng } 1.4 \\
-10 \cdot 0 \\
4 \cdot 2\end{array}$ & $\begin{array}{r}58 \cdot 7 \\
-42 \cdot 6 \\
26 \cdot 0 \\
\quad 1 \cdot 2 \\
\text { ng } \\
\text { ng } \\
-4 \cdot 0 \\
-17.9 \\
-24.9\end{array}$ \\
\hline
\end{tabular}

ng: Negligible (less than 1\%).

* Am is defined by the equation in the sensitivity analysis section.

$+\%$ Change is defined as:

$\%$ Change $=\frac{\text { Control Am }- \text { Perturbed Am }}{\text { Control Am }} \times 100$

where the perturbed Am is calculated when a parameter was increased to $200 \%$.

Table 9 Application of the physiological model to the risk assessment posed by TRI and TETRA via drinking water ingestion

\begin{tabular}{|c|c|c|c|c|}
\hline & \multicolumn{2}{|l|}{$T R I$} & \multicolumn{2}{|l|}{ TETRA } \\
\hline & Exposure & Amst (mg/day) & Exposure & Amst (mg/day) \\
\hline $\begin{array}{l}\text { Rat: } \\
\quad(250 \mathrm{~g}) \\
\text { Non-cancert inducing dose }\end{array}$ & $\begin{array}{l}\text { Inhalation } \\
500 \mathrm{ppm} \times 6 \mathrm{~h} / \text { day, } 5 \text { days/week }\end{array}$ & $74 \cdot 6^{*}$ & $\begin{array}{l}\text { Inhalation } \\
600 \mathrm{ppm} \times 6 \mathrm{~h} / \text { day, } 5 \text { days/week }\end{array}$ & $11 \cdot 2^{*}$ \\
\hline $\begin{array}{l}\text { ( } 70 \text { kg) } \\
\text { Drinking water }\end{array}$ & $\begin{array}{l}32 \mathrm{ppb} \times 21 \ddagger \\
\text { Day }\end{array}$ & $\begin{array}{l}6.97 \\
\times 10^{-4}\end{array}$ & $5 \mathrm{ppb} \times 2$ i & $\begin{array}{l}4.63 \\
\times 10^{-5}\end{array}$ \\
\hline
\end{tabular}

*Amst were calculated under steady state conditions ( 50 days after initiation of the exposure) after repeated exposures, where day by day differences of the metabolised amounts were within $1 \%$. See "risk assessment" for details.

tReported exposure intensity at which either TRI or TETRA did not induce extra cancers. For TRI Henschler et al ${ }^{14}$ and for TETRA Rampy et al ${ }^{15}$

†Highest concentration ever reported in the United States (see text).

together, it may be said that those parameters that determine the metabolic capacity or exhaled/uptake of the chemicals from the lung have a greater influence on Am than any others. Fortunately, blood/air partition coefficient and alveolar ventilation rate are easily measurable while Vmax remains in the "black box." Thus it may reasonably be concluded that physiologically based pharmacokinetics can provide solid simulation results even with perturbations in the parameters, so long as a sound Vmax is used.

Risk assessment is one of the most promising areas to which the PPM can contribute. This is mainly due to capability of establishing dose response relations by compiling diverse kinetic data obtained in man or animals under different regimens and different routes as shown in a case of methylene chloride. ${ }^{18} \mathrm{~A}$ great number of uncertainties, however, are involved in the evaluation of human risk from the results of chronic animal studies. The goal of the present paper is not to provide a comprehensive strategy and discussion of all factors and thus my discussion is restricted to the role of PPM in human risk assessment by amalgamating chronic animal bioassay data and influences of parameter perturbation on the results. The species difference is one of the most critical issues associated with the human risk assessment using animal data. For both TRI and TETRA, accumulated evidence indicates that, in most cases, these chemicals induce hepatocellular carcinomas only in mice, not in rats. ${ }^{1519-21}$ Recent evidence also suggests that metabolic capacity and the rate of formation of trichloroacetic acid, which is considered to play a major part in 
carcinogenesis through peroxisome proliferation, is far greater in mice than in rats after exposure to these compounds. ${ }^{22-24}$ Thus metabolic capacities-that is, Vmax - in mice appeared to be far greater than in rats. $^{72325}$ The larger metabolic capacities for TRI and TETRA in mice than in rats are correlated with the higher incidences of hepatocellular carcinomas in this species than in rats. ${ }^{722-26}$ In the present study a PPM using the Vmax obtained from rat data was proved to be applicable to fates of these chemicals in man, suggesting that standardised metabolic capacities in rats and man are similar to each other. Thus I believe the use of chronic bioassay data on TRI and TETRA in rats is justifiable to formulate the risks in man, at least on the basis of rule of thumb, posed by these compounds. As shown in table 9, we could compare the risk posed by daily intake of drinking water with the risk posed by inhalation on the basis of internal doses. Using simulation, I could show that the relative risk posed by consuming the drinking water in man was about fifth in order of magnitude less than the non-cancer causing doses for TRI and TETRA in rats (table 9). If the sensitivity of man to tumours is assumed to be similar or at least close to that of rats, then the maximised human risk posed by the drinking water consumption is conceivably estimated as fifth in order of magnitude less than non-tumour causing doses in rats. The differences of fifth in order of magnitude is too large to be perturbed significantly by small changes of parameters as shown by sensitivity analysis. Thus it may be reasonably speculated that carcinogenic effects due to ingesting TRI and TETRA in drinking water may be negligible, if any. Obviously, however, it is needless to say that for those chemicals to which the sensitivity of man is quite different, or of which target organs or metabolic pathway or mechanism is entirely different, PPM has only limited applicability in risk assessment to amalgamate chronic animal bioassay data.

Another example of application of PPM is to find out maximally permissible values under various conditions. As shown in table 6, PPM can simulate maximally permissible values for biomonitoring exposure intensities to TRI and TETRA that have been determined by accumulated field studies. This means that maximally permissible values may be a priori predicted without accumulating historical data, if a reasonable PPM model is constructed. Superiority of this simple approach to the traditional way is obvious in view of time, cost, and labour. Minor extensions of the present model, however, might be necessary to simulate fates of chemicals accurately under various scenarios. These scenarios should cover exposure situations under varieties of workload or fluctuations of exposure intensities. The former situation may need another compartment such as a "muscle and skin" compartment, since workload may change the blood $\frac{3}{\infty}$ flow in muscle and skin to a substantial degree and $?$ thereby change the blood distribution together with $\vec{F}$ increase in cardiac output. ${ }^{27}$ The latter situation is also $\frac{7}{0}$ important since in the actual situation exposure doses are stochastic in nature. Therefore, it is required to $\frac{\bar{\omega}}{\mathrm{c}}$ determine as to what simulated values can be used to $\widetilde{\Phi}$ monitor the probable risks posed by a given chemical $\propto$ as theoretically considered by Roach ${ }^{28}$ and Koizumi os et al. ${ }^{29}$

In conclusion, the use of physiologically based pharmacokinetic model with unified algorithm of $\vec{\omega}$ parameter estimation seems promising in various $\stackrel{\circ}{\circ}$ fields. This approach will enable us to assess the $\frac{\mathbb{}}{3}$ toxicity of chemicals in man by compiling diverse dose response relations in animals.

I am grateful to Dr S A Roach, the Central Medical N $_{0}^{\text {S }}$ Group, ICI UK, for his encouragement and instruc-응

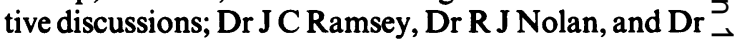
R H Reitz; The Dow Chemical Company, Midland $\triangle$ Michigan USA; Dr M E Anderson, Armstrong Aero-을. space Medical Research Laboratory, Wright $\overrightarrow{\vec{O}}$ Patterson AFB, Ohio, USA; and Professor A Sato, Yamanashi Medical College, Yamanashi, Japan.

\section{Appendix}

The physiologically based pharmacokinetic model (fig 1) is described mathematically by a set of simultaneous differential equations. The model is composed of five tissues: lung, fat, rapidly perfused tissue, slowly perfused tissues, and liver. The mathematical equations described by Ramsey and Andersen' are used with ${ }_{\infty}$ minor modifications. The equations are briefly des- $\bar{F}$ cribed:

Lung compartment:

$$
\begin{gathered}
\mathbf{Q}_{\mathrm{alv}}\left(\mathrm{C}_{\mathrm{inh}}-\mathrm{C}_{\mathrm{alv}}\right)=\mathrm{Q}_{1}\left(\mathrm{C}_{\mathrm{art}}-\mathrm{C}_{\mathrm{ven}}\right) \\
\mathrm{N}=\mathrm{C}_{\mathrm{arr}} / \mathrm{C}_{\mathrm{alv}}
\end{gathered}
$$

where $\mathrm{N}$ is blood/air partition coefficient.

Mass balance across the lung yields:

$$
C_{\text {art }}=\frac{Q_{\text {alv }} C_{\text {inh }}+Q_{1} C_{\text {ven }}}{\left[Q_{1}+Q_{\text {alv }} / N\right]}
$$

On cessation of inhalation exposure (or when other routes of administration are used), the vapour concen- $?$ tration in inhaled air is zero. By assuming that alveolar 0 respiration accounts for $70 \%$ of total respiration, the vapour concentration in exhaled air is given by

$$
C_{\text {exh }}=0.7 C_{\text {alv }}+0.3 C_{\text {inh }}
$$


Tissue concentrations: Tissue concentrations are given by the following set of equations:

$$
\begin{gathered}
d A_{i} / d t=Q_{i}\left(C_{a r t}-C_{v i}\right) \\
C_{i}-A_{i} / V_{i} \\
C_{v i}=C_{i} / P_{i}
\end{gathered}
$$

where $Q_{i}, C_{i}$, and $V_{i}$ represent blood flow, concentration, and volume of a given organ " $i$ ", respectively and $P_{i}$ stands for a blood organ partition coefficient. Metabolism in the liver: The metabolism of the TRI and TETRA is assumed to occur only in the liver. The rate of metabolism was described by a MichaelisMenten type of equation:

$$
\mathrm{dA}_{\mathrm{m}} / \mathrm{dt}=\frac{\mathrm{V}_{\max } \mathrm{C}_{\mathrm{vl}}}{\mathrm{Km}+\mathrm{C}_{\mathrm{vl}}}
$$

TRI and TETRA in drinking water are assumed to be drunk and absorbed as a zero order rate and are added to the mass balance differential equation for the liver:

$$
\begin{gathered}
\mathrm{dA}_{1} / \mathrm{dt}=\mathrm{Q}_{1}\left(\mathrm{C}_{\mathrm{art}}-\mathrm{C}_{\mathrm{v} 1}\right)-\mathrm{dAm} / \mathrm{dt}+\mathrm{K}^{0} \\
\mathrm{C}_{1}=\mathrm{A}_{\mathrm{l}} / \mathrm{V}_{1} \\
\mathrm{C}_{\mathrm{vl}}=\mathrm{C}_{1} / \mathrm{P}_{1}
\end{gathered}
$$

Venous return:

$$
\mathrm{C}_{\mathrm{v}}=\left[\Sigma\left(\mathbf{Q}_{\mathrm{i}} \mathrm{C}_{\mathrm{v}}\right)\right] / \mathbf{Q}_{\mathrm{t}}
$$

\section{References}

1 Andersen ME. Saturable metabolism and its relationship to toxicity. CRC Crit Rev Toxicol 1981;12:105-50.

2 Ramsey JC, Andersen ME. A physiologically based description of the inhalation pharmacokinetics of styrene in rats and humans. Toxicol Appl Pharmacol 1984;73:159-75.

3 Koizumi A, Kumai M, Ikeda K. Dose-dependent induction and suppression of liver mixed function oxidase system in chlorinated hydrocarbon solvent metabolism. J Appl Toxicol 1983;3:208-17.

4 Franz SW, Watanabe PG. Tetrachloroethylene: balance and tissue distribution in male Sprague Dawley rats by drinking water administration. Toxicol Appl Pharmacol 1983;69:66-72.

5 Davis NR, Mapleson WW. Structure and qualification of a physiological model of the distribution of injected agents and inhaled anaesthetics. Br J Anaesth 1981;53:399-405.

6 Sato A, Nakajima T. Partition coefficients of some aromatic hydrocarbons and ketones in water, blood, and oil. Br JInd Med 1979;36:231-4.

7 Stott WT, Quast JF, Watanabe PG. The pharmacokinetics and macromolecular interactions of trichloroethylene in mice and rats. Toxicol Appl Pharmacol 1982;62:137-51.

8 Pegg DG, Zampel JA, Barun WH, et al. Disposition of tetrachloro(14C)ethylene following oral and inhalation exposure in rats. Toxicol Appl Pharmacol 1979;51:465-74.

9 Agin GL, Blau GE. Application of DACSL (Dow advanced continuous simulation language) to the design and application of chemical reactor system. American Institute of Chemical Engineers Symposium Series 1982;78:108-18.

10 Withey JR, Collins BT. Chlorinated aliphatic hydrocarbons used in the foods industry: the comparative pharmacokinetics of methylene chloride, 1,2-dichloroethane, chloroform and trichloroethylene after IV administration in the rat. $J$ Toxicol Environ Health 1980;3:313-32.

11 Sato A, Nakajima T. Differences following skin or inhalation exposure in the absorption and excretion kinetics of trichloroethylene and toluene. Br J Ind Med 1978;35:43-9.

12 Monster AC, Boersma G, Steenworker H. Kinetics of tetrachloroethylene in volunteers: influence of exposure concentration and workload. Int Arch Environ Health 1979;42:303-9.

13 Commision of the European Committees. EUR 8476-human biological monitoring of industrial chemical series ECSC-EEC$E A E C$. Luxemburg, EEC, 1983.

14 Henschler D, Romen W, Elasasser HM, et al. Carcinogenicity study of trichloroethylene by long-term inhalation in three animal species. Arch Toxicol 1980;43:237-48.

15 Rampy LW, Quast JF, Leong BKJ, et al. Results of long-term inhalation toxicity on rats of 1,1,1-trichloroethane and perchloroethylene formulations. In: Plaa GL, Duncan WAM, eds. Proceedings of the first international congress on toxicology, San Diego 1978. New York: Academic Press, 1978:562.

16 Environmental Protection Agency. Preliminary assessment of suspected carcinogenes in drinking water. Washington: Office of Toxic Substances. 1975. (Draft report for Congress (1975).)

17 Dowty BJ, Carlisle DR, Laseter JL, et al. Halogenated hydrocarbons in New Orleans drinking water and blood plasma. Science 1975;187:75-7.

18 Andersen ME, Clewell HJ III, Gargas ML, et al. Physiologically based pharmacokinetics and the risk assessment process for methylene chloride. Toxicol Appl Pharmacol 1987;87:185-205.

19 National Cancer Institute. Carcinogenesis bioassay of trichloroethylene. Washington: DHEW, 1976. (CAS No 79-01-6, DHEW publ No (NIH) 76-802.)

20 National Toxicology Program. National toxicology program draft report abstracts on nine chemical carcinogenesis animal bioassay. Chemical Regular Reports 1983;6:767-8.

21 National Cancer Institute. Bioassay of tetrachloroethylene for possible carcinogenicity. Washington: DHEW, 1977. (DHEW, pub No (NIH) 77-813.)

22 Green T, Prout MS. Species differences in response to trichloroethylene. II. Biotransformation in rats and mice. Toxicol Appl Pharmacol 1985;79:401-11.

23 Prout MS, Provan WM, Gree T. Species differences in response to trichloroethylene. I. Pharmacokinetics in rats and mice. Toxicol Appl Pharmacol 1985;79:389-400.

24 Herren-Freund SL, Pereira MA, Khoury MD, et al. The carcinogenicity of trichloroethylene and its metabolites, trichloroacetic acid and dichloroacetic acid, in mouse liver. Toxicol Appl Pharmacol 1987;90:183-9.

25 Schumann AM, Quast JF, Watanabe PG. The pharmacokinetics and macromolecular interactions of perchloroethylene in mice and rats as related to oncogenicity. Toxicol Appl Pharmacol 1980;55:207-19.

26 Nakajima T, Okino T, Okuyama S, et al. Ethanol-induced enhancement of trichloroethylene metabolism and hepatotoxicity; difference from the effect of phenobarbital. Toxicol Appl Pharmacol 1988;94:227-37.

27 Åstrand I, O̊vrum P. Exposure to trichloroethylene. I. Uptake and distribution in man. Scand J Environ Health 1976;4:199-211.

28 Roach SA. A most rational basis for air sampling programs. Ann Occup Hyg 1977;20:65-84.

29 Koizumi A, Sekiguchi T, Konno M. Evaluation of the time weighted average of air contaminants with special references to concentration fluctuation and biological half time. Am Ind Hyg Assoc J 1980;41:693-9. 